\title{
Groundwater Inhabitants in Poland
}

\author{
by
}

Andrzej W. SKALSKI*

This paper gives a review of the present knowledge of the ground (underground) water fauna of Poland. This fauna inhabits different biotopes of the aqueous media which constitute a broad aquatic environment of the subterranean life zone. The organisms associated with both subterranean (endogeous) waters and interstitial medium are discussed here. The subterranean waters are understood in a broad sense as those infiltrating or accumulated in large chambers or channels and small spaces in rock beds mainly limestones. They form mostly large aquifers associated with various geological levels at varying depths from the surface. In the interstitial medium different biotopes have been distinguished, but only phreatic and parafluvial nappes are discussed by Vandel (1965) as true underground habitat. Because the surface sandy interstitial layer in many respects occupies an intermediate place between subterranean and epigeous environments, it has also been included in this paper.

In Poland the best known are those subterranean aquifers which are accessible for collection and study via entrances of caves, artificial galleries, wells, springs and seeps. Some hypogeous forms, in particulary gammarids belonging to the genus Niphargus, were found in mountain lakes and streams. The cave waters received special attention and were intensively investigated by many speleologists and biologists (Skalska \& Skalski, 1969). Larger water reservoirs are found only in some caves of the Tatra Mts. and the Sudeten Mts. By now about 1000 caves are known in Poland, with $20 \%$ of them located in the Tatra Mts. and $4 \%$ in the Sudeten Mts. On the other hand, biological data form underground waters of non-cavernous areas are fragmentary or virtually nonexistant (most of Middle and North Poland).

Those subterranean waters for which biological data exist are very unequally

* Muzeum w Czestochowie 42-200 Czestochowa, Ratusz, Poland. 
distributed in Poland. The most intensive investigations took place only in mountain and submountain regions of the country; the Tatra Mts. (Wrześniowski, 1888, 1890; Kowalski, 1955; Chodorowska \& Chodorowski, 1958, 1963; Doroszewski, 1960, 1963; Fischer, 1963; Pròszyńska, 1963; Skalski, 1967; Gadzińska, 1974), the Beskid Mts. (Kowalski, 1954) and the Sudeten Mts. (Arndt, 1921, 1923; Pateff, 1926; Moszyński, 1936; Pax, 1936; Pax \& Maschke, 1935; Stammer, 1936a, 1936b). Wrześniowski $(1888,1890)$ was the first in Poland to find in wells of Zakopane, obligate underground-dwelling organisms. The fauna of wells was also examined in Kraków and Lwów (Jaworowski, 1893a, 1893b 1895), in Krosno on the Oder (Haeckel, 1908), in Kazimierz Dolny on the Vistula (Skalski in litt.) and recently in some places in the Carpathians by Dr. T. Sywula (Biesiadka, 1975). Most of these researches are concentrated upon faunistical and systematical problems. Among all the animals occurring in subterranean waters of Poland only the Gammaridae were intensively studied and are better known taxonomically (Wrześniowski, 1888, 1890; Jaworowski, 1893b, 1895; Grochowski, 1904; Schellenberg, 1933, 1935, 1937; Micherdziński, 1856; Skalski, 1970, 1972, in litt.; Karaman, 1974). Also Ostracoda (Sywula, 1974a, 1974b) and Hydracarina (Biesiadka, 1975) of that are studied in modern aspect.

Interstitial waters are an environment rarely studied in Poland. Only some groups associated with them have been examined; Turbellaria (Gieysztor, 1938) of the sandy beaches of the Wigry lake, and Rotatoria (Wiszniewski, 1934a, 1934b, 1935, 1936a, 1936b, 1937, 1954) of sandy beaches of some lakes and rivers in Middle and North Poland, Gastrotricha (Roszczak, 1939) and Rhizopoda of the sandy beaches along the border of the Baltic sea (Golemans$\mathrm{ky}, 1970$, 1973, 1974a), Hydracarina of the parafluvial nappes of some Carpathian rivers (Biesiadka, 1972, 1974, 1975) and Ostracoda of that of the Raba river (Sywula, 1974a).

The ecology and biology of the fauna of subterranean and interstitial waters have been practically limited to the cave waters particulary of the Tatra Mts. (Chodorowski. 1959; Chodorowska \& Chodorowski, 1960).

As a result of these researches about 200 species of invertebrates have been recorded in all types of underground waters in Poland. The maiority of these have entered into this environment quite accidertally from the surface. Limitations upon space make it impossible to list here all those species recorded in the underground waters of Poland. Only true underground forms, stygobionts or troglobionts according to biospeleological terminology, and phreatobionts are listed below. Psammobionts have been listed separately. The species in italics have been described from territory of Poland; those marked with an asterisk are known from Poland to this moment. 


\section{Archiannelida}

\section{STYGOBIONTS AND PHREATOBIONTS}

Troglochaetus beranecki Delachaux - found in the Jaskinia w Rogózce cave and the Radochowska cave* in the Sudeten Mts. (Maschke, 1936; Stammer, 1936b).

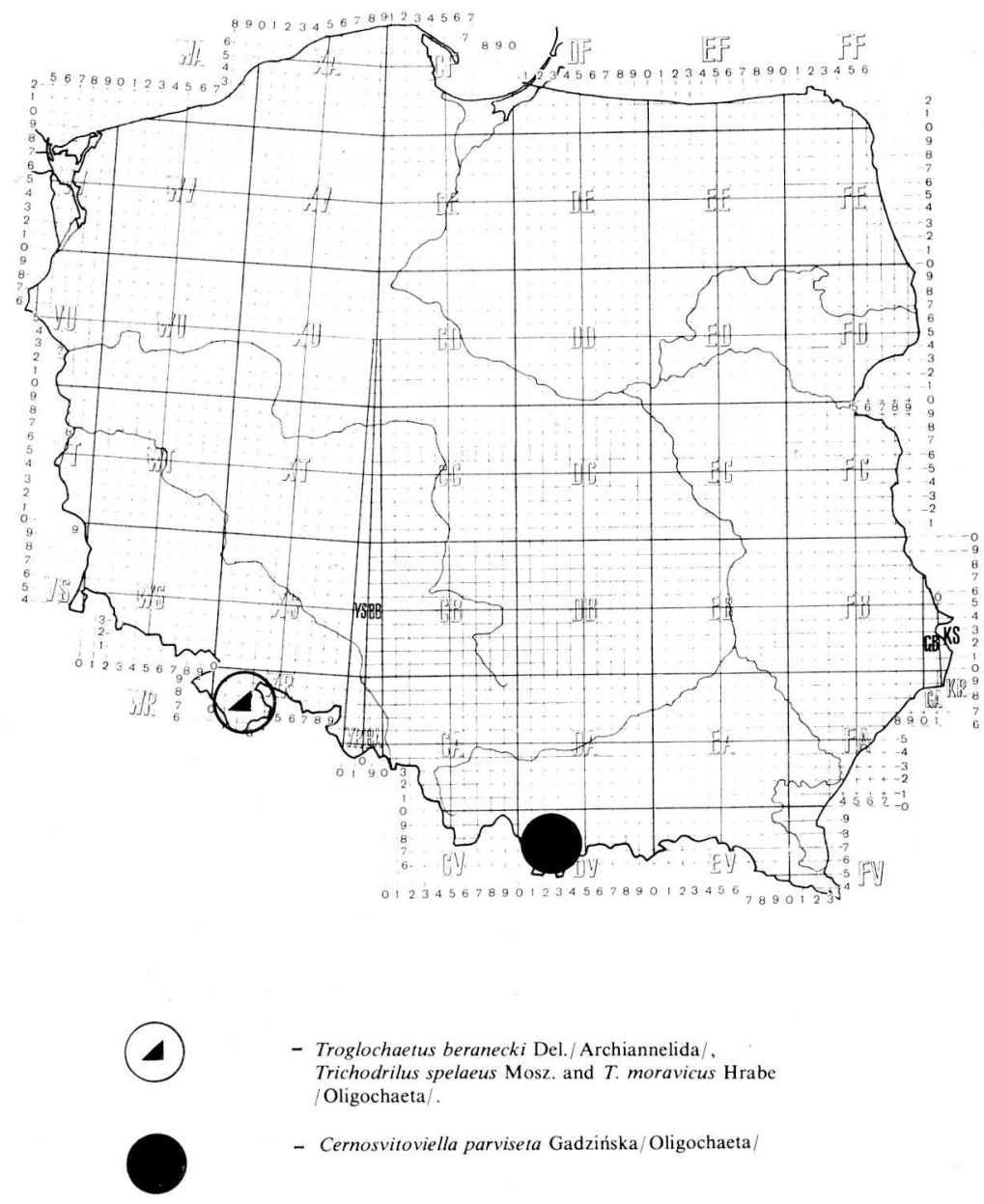

1. Distribution of Archiannelida and Oligochaeta. Distribution of some stygobionts based on the U.T.M. grid accepted by the European Invertebrate Survey.

* Names of caves after Kowalski (1951-1954). 


\section{Oligochaeta}

*Cernosvitoviella parviseta Gadzińska - known from the Zimna cave in the Tatra Mts.; *Trichodrilus spelaeus Moszyński — known from subterranean waters of Klecienko in the Sudeten Mts.; T. moravicus Hrabe - in subterranean waters of Śnieznik Klodzki in the Sudeten Mts. (Moszyńska, 1962).

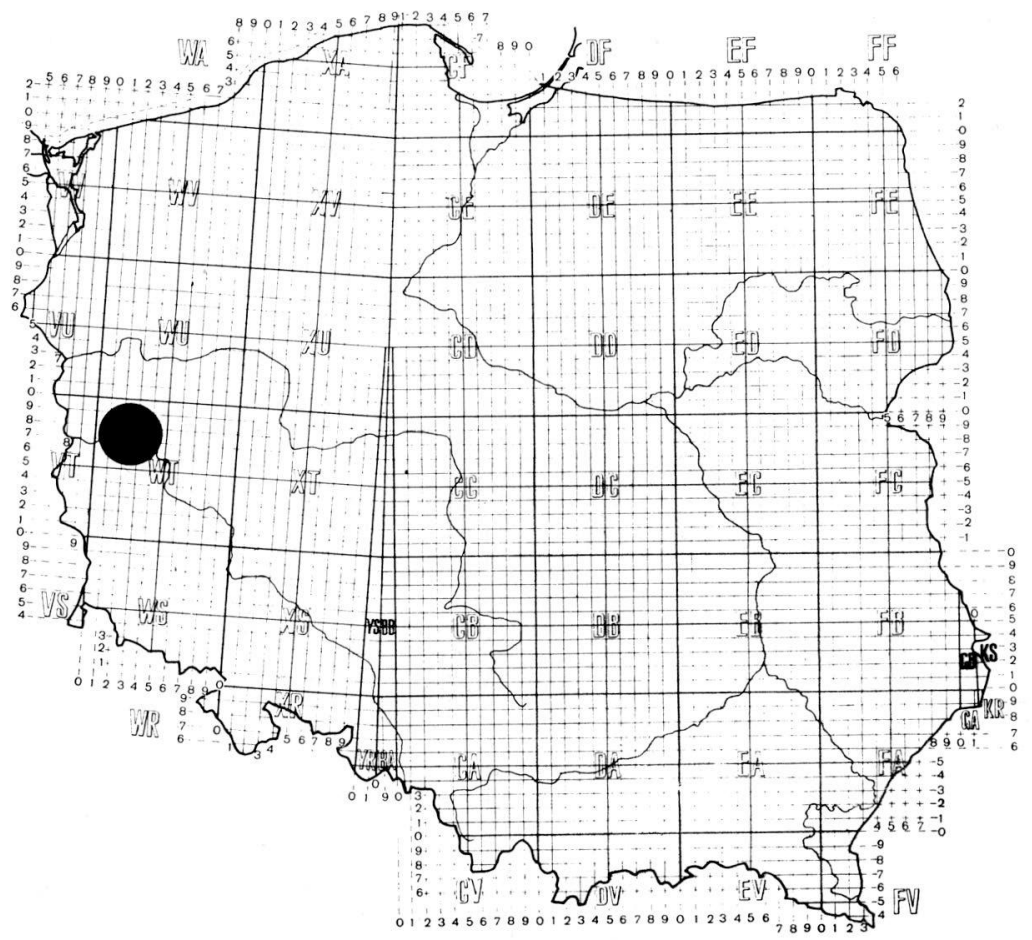

2. Distribution of Balcanohydracarus corsicus E. Angelier (Hydracarina) a species known from interstitial waters of Corsica found in underground waters of all continental Europe by Dr. T. Sywula (Biesiadka, 1975). 


\section{Hydracarina}

*Spherchon carpathicus Biesiadka, *Spherchonopsis phreaticus Biesiadka, Kawamuracarus chappuisi Motas and Tanasachi, Atractides latipalpis (Motas and Tanasachi), A. pilosus Schwoerbel, A. primitivus (Walter), ${ }^{*}$ A. gorcensis Biesiadka, ${ }^{*} A$. barbarae Biesiadka, Azugofeltria mira Motas and Tanasachi, Lethaxona cavifrons Szalay, Erebaxonopsis brevipes Motas and Tanasachi, ${ }^{*}$ Axonopsis cogitatus Biesiadka, ${ }^{*}$ A. monstrabilis Biesiadka, Frontipodopsis reticulatifrons Szalay, ? Aturus pauciporus Walter, ${ }^{*}$ A. pulchellus Biesiadka, Kongsbergia alata Szalay, K. dentata Walter, Stygomomonia latipes Szalay, Neoacarus hibernicus Halbert, Hungarohydracarus subterraneus Szalay, Balcanohydracarus corsicus E. Angelier, Lobohalacarus weberi quadriporus (Walter) - found in wells and interstitial waters of parafluvial nappes in South Poland, mainly surround some Carpathian streams and rivers. In underground waters of Poland 40 species of Hydracarina have been recorded (Biesiadka, 1975).

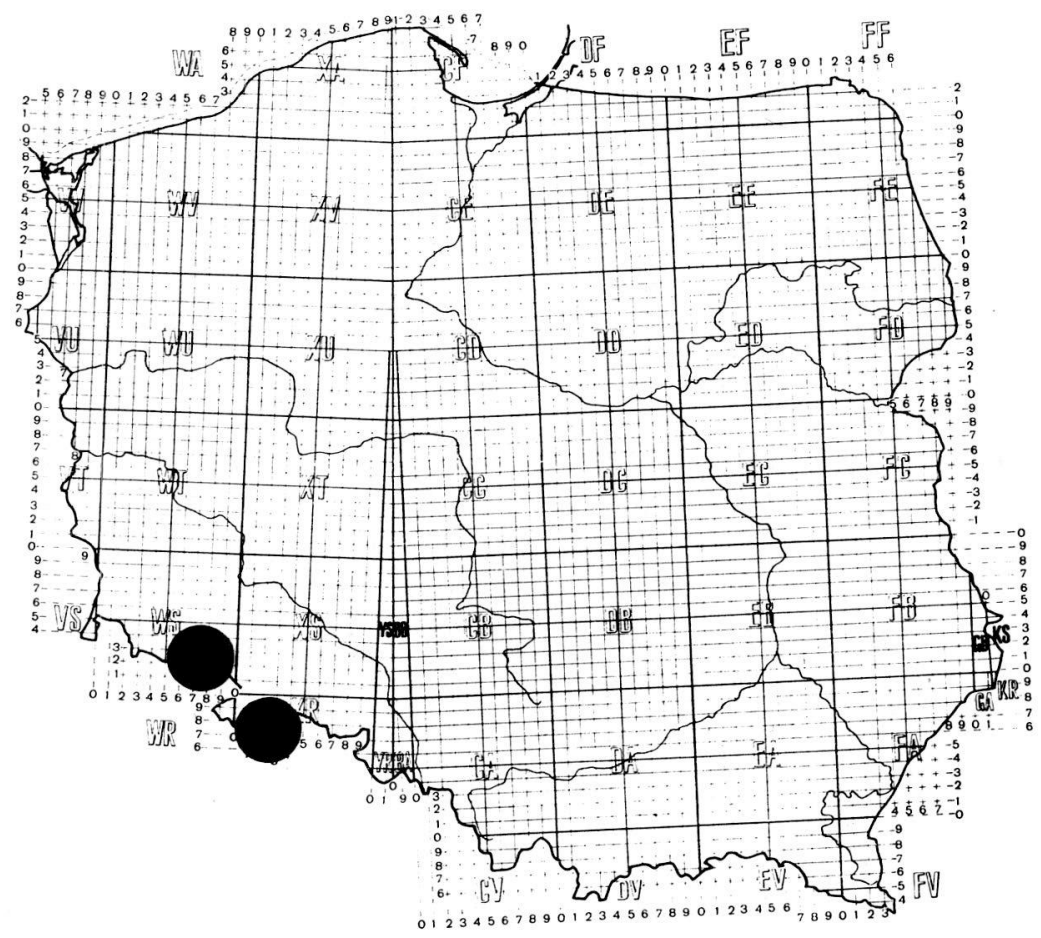

3. Distribution of Niphargellus arndti Schell. (Amphipoda). 


\section{Ostracoda}

Candona wegelini Petkovski - found in interstitial waters of parafluvial nappes of the Raba river (Sywula, 1974a), Cypridopsis subterranea Wolf - found in the environs of Klodzko and the Gorce Mts. (Sywula, 1974b).

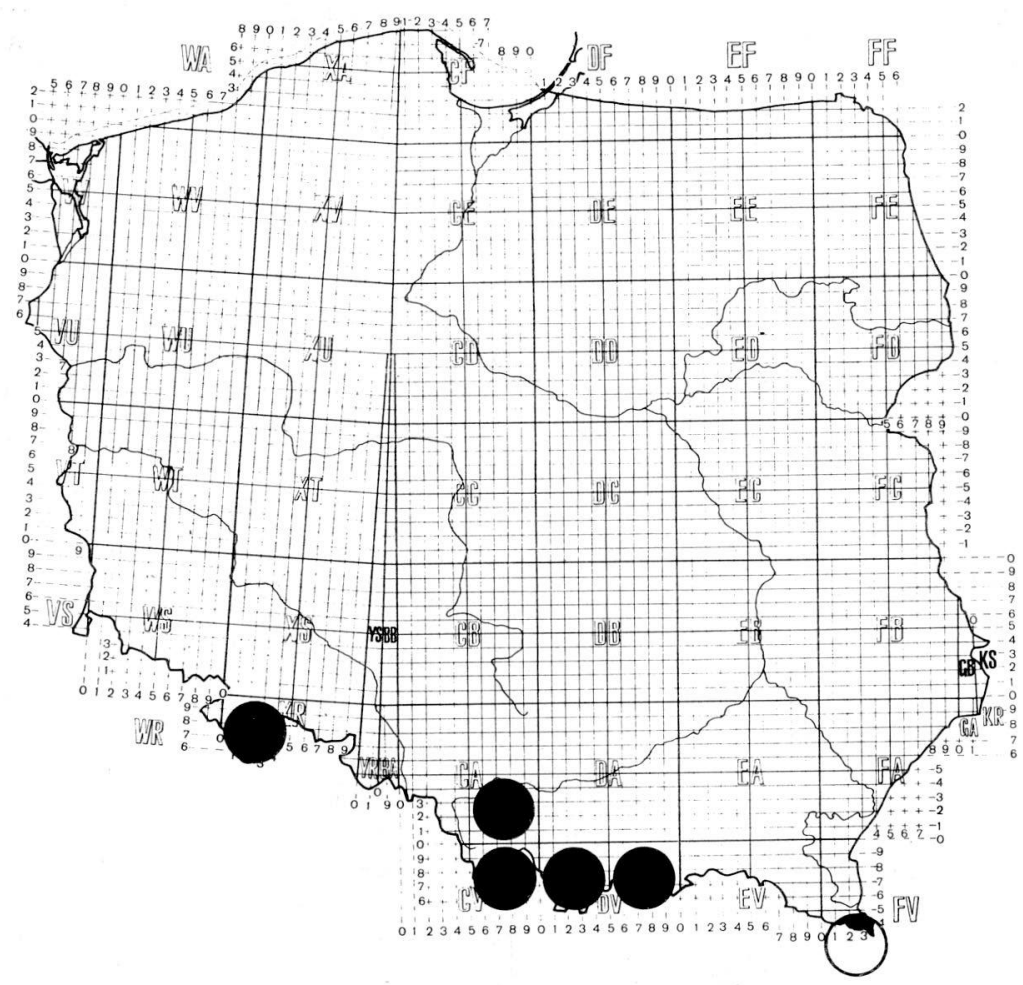

4. Distribution of Niphargus tatrensis Wrześn. (Amphipoda). 


\section{Copepoda}

Acanthocyclops longuidoides var. clandestinus (Kiefer) - found in the Zimna cave in the Tatra Mts. (Prószyńska, 1963), *Nitocrella hibernica var. hyalina (Jakubisiak) - described from water pipings of Poznań (Jakubisiak, 1929).

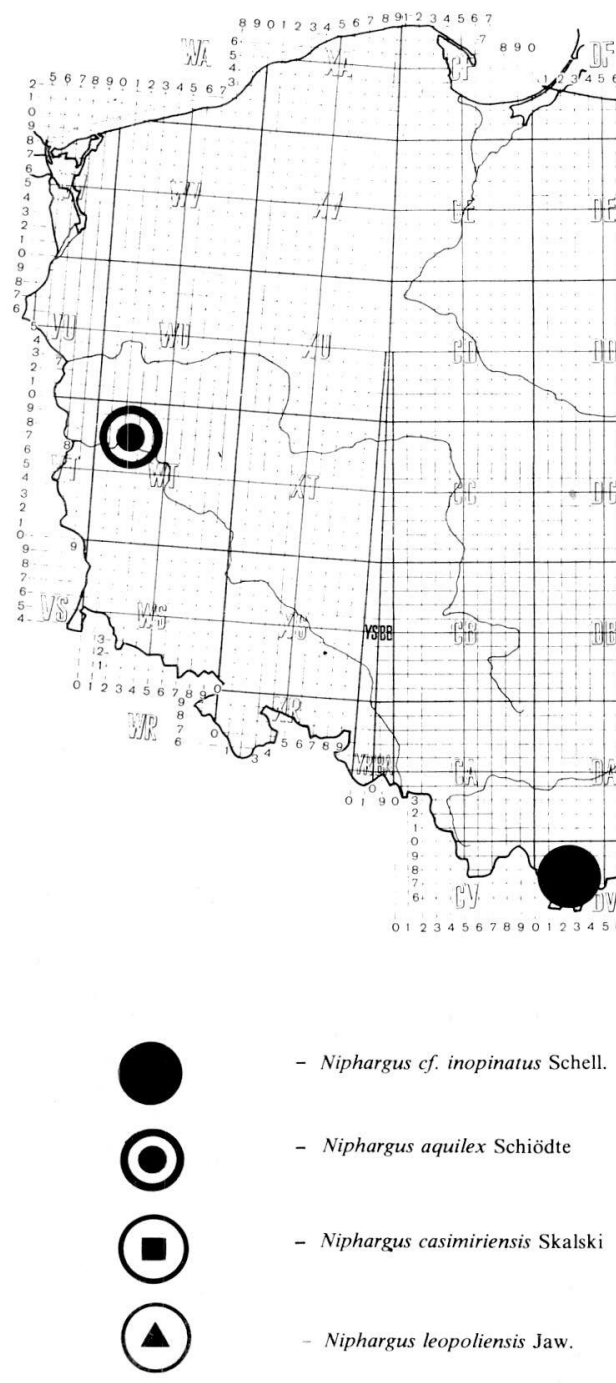

5. Distribution of some Niphargus species (Amphipoda). 


\begin{abstract}
Amphipoda
Synurella ambulans form tenebrarum Wrześniowski - known from specimens collected by Prof. A. Wrześniowski in two wells at Zakopane, reported also from caves in Czechoslovakia (Hrabe, 1954); *Crangonyx paxi Schellenberg known from specimens collected by Prof. F. Pax in an artificial gallery in the Śnieznik Klodzki region in the Sudeten Mts. (Schellenberg, 1935), its systematic position is unclear; Niphargellus arndti Schellenberg - distributed in the Sudeten Mts., caves and springs; ? Niphargus aquilex Schiödte - recorded from a well in Krosno on the Oder (Haeckel, 1908); N. cf. inopinatus Schellenberg - Prof. F. Pax collected two specimens in a spring in Jaszczurówka near Zakopane, these specimens differ by some characters from the type form; $N$. leopoliensis Jaworowski - common in seeps in the Bieszczady Mts.; N. tatrensis Wrześniowski - wide distributed and common in the Carpathians and the Sudeten Mts., caves, springs, seeps, lakes and streams; ${ }^{*} N$. casimiriensis Skalski - common in wells of Kazimierz Dolny on the Vistula.
\end{abstract}

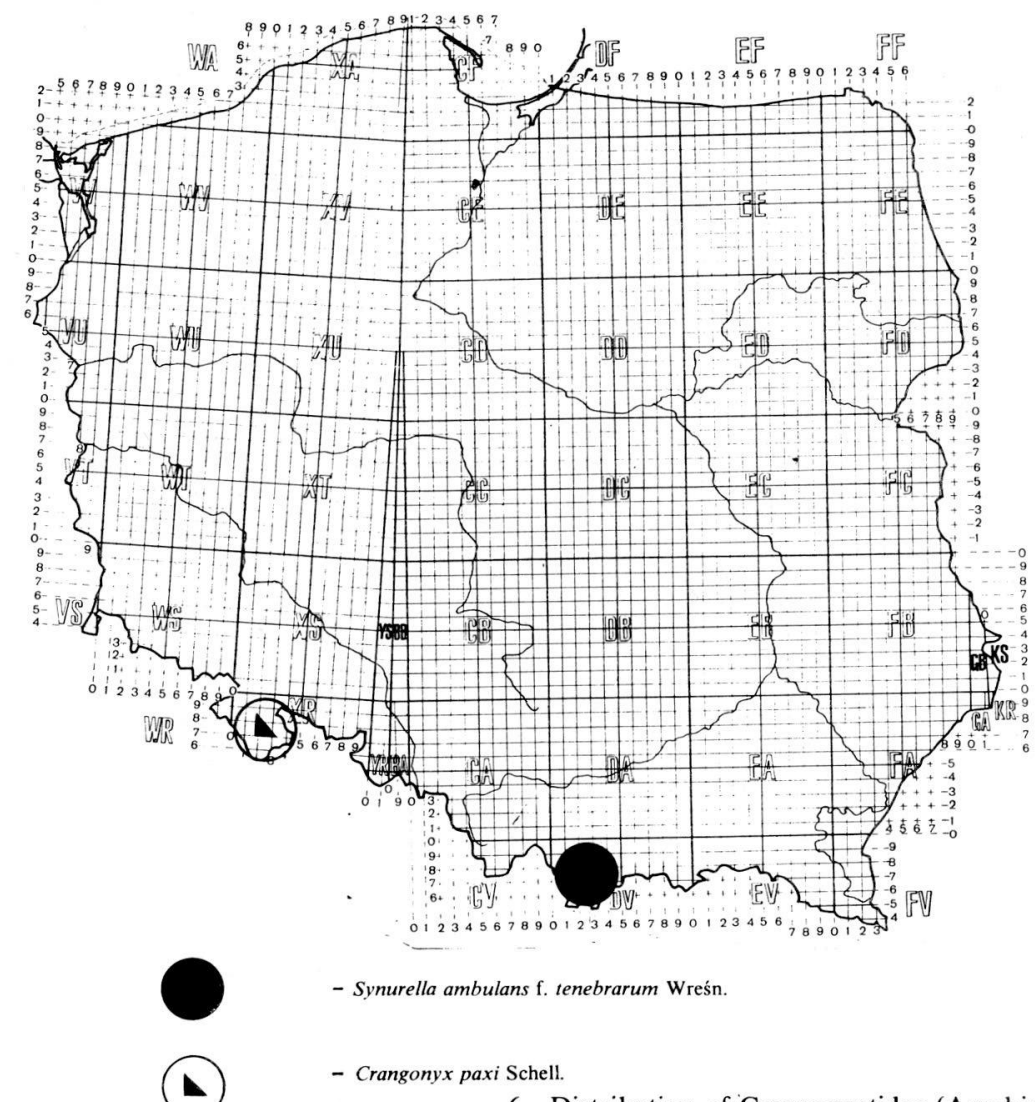

6. Distribution of Crangonyctidae (Amphipoda). 


\section{Rhizopoda}

\section{PSAMMOBIONTS}

Pseudocorythion acutum (Wailes) Valkanov, Psammonobiotus communis Golemansky, P. linearis Golemansky, P. balticus Golemansky, Corythionella minima Golemansky, C. acola Golemansky, Cyphoderia littoralis Golemansky, Micropsammella retorta Golemansky, Micramphora pontica Valkanov, Centropyxiella arenaria Valkanov, Cryptodifflugia lanceolata Golemansky, Difflugiella psammophila Golemansky, Microchlamys patella Clap. and Lachmann, Amphorellopsis elegans Golemansky, Hyalosphaenia cuneata Stein., Euglypha rotunda Wailes, Lagenidiopsis valkanovi Golemansky - found in interstitial waters of the sandy beaches of the Baltic sea. Some genera belong to the lately erected family Psammonobiotidae (Golemansky, 1974b) which grouped forms typical for the biocenosis of interstitial ground waters of sea littoral (Golemansky, 1969).

\section{Turbellaria}

* Gieystoria wiszniewskii (Gieysztor) - Interstitial waters of the sandy beaches of the Wigry lake (Gieusztor, 1938).

\section{Rotatoria}

Aspelta egregia Myers, Cephalodella compacta Wiszniewski, C. megalotrocha Wiszniewski, Dicranophorus hercules Wiszniewski, D. leptodon Wiszniewski, Elosa spinifera Wiszniewski, Encentrum diglandula (Zawadowsky), E. sutor Wiszniewski, ? E. wiszniewskii Wulfert, Erignatha sagittoides Wiszniewski, Lecane psammophila (Wiszniewski), Lindia janickii Wiszniewski, Myersinella tetraglena (Wiszniewski), Notommata diasema Myers, Trichocerca intermedia arenosa Wiszniewski, T. pygocera Wiszniewski, T. taurocephala Hauer, Wierzejskiella elongata (Glascott), W. sabulosa (Wiszniewski), W. velox (Wiszniewski), Wigrella depressa Wiszniewski - found in interstitial waters of the sandy beaches of some reservoirs in North-Eastern Poland. In psammon Wiszniewski (1954) found 113 species of Rotatoria, among these he recognized the above mentioned as true psammobionts.

\section{Gastrotricha}

Xenotrichula bispina Roszczak, Chaetonotus balticus (Roszczak), Lepidodasys platyurus Remane - sandy beaches of the Baltic sea.

\section{REMARKS}

The fauna of the subterranean aquatic environment in Poland is very poor. This phenomenon has generally been attributed to past glacial conditions which destroyed forms that inhabited circumboreal regions during the Tertiary. Certain ancient forms, e.g. Troglochaetus or Niphargus, persisted in refuges particulary in the Carpathians and Sudeten Mts. Other colonized subterranean environment during the post glacial period. Because the studies on the interstitial medium have recently been initiated in Poland this list will be completed in near future. Also, the systematic status of some forms must be revised. 


\section{ACKNOWLEDGMENTS}

I wish to acknowledge the Deutschen Forschungsgemeinschaft for supporting my participation in 3rd International Colloquium on Gammarus and Niphargus, and 1st International Symposium on Groundwater Ecology. I am indebted to Dr. S. Husmann and Dr. M. P. D. Meijering, Limnologische Flussstation des Max-Planck-Instituts für Limnologie in Schlitz, for their various help. I am also deeply indebted to Dr. T. Gledhill, Frishwater Biological Association, Dorset, for critical review of the paper.

\section{SUMMARY}

This paper states the present progress achieved in research regarding the ground-water fauna of Poland.

\section{RÉSUMÉ}

Cet article présente l'état actuel des recherches sur la faune des eaux souterraines de la Pologne.

\section{ZUSAMMENFASSUNG}

In der vorliegenden Arbeit wird ein Abriss zum Erforschungsstand der Grundwasserfauna in Polen gegeben.

\section{REFERENCES}

Arndt, W. (1921) - Beitrag zur Kenntnis der Höhlenfauna. Ergebnis einer faunistischen Untersuchung der Höhlen Schlesiens. - Zool. Anz. 52, 12/13: 310-315.

Arndt, W. (1923) - Speläobiologische Untersuchungen in Schlesien. — Speläologisches Jahrbuch 4: $95-114$

Biesiadka, E. (1972) - Sur quelques Hydracariens nouveaux recueillis en Pologne. - Bull. Acad. pol. Sci. ser. biol. 20: 249-256.

Biesiadka, E. (1974) - Hydracarina of the River Raba and some of its tributaries. - Acta hydrobiol. 16, 1: 31-50.

Biesiadka, E. (1975) - Material y do znajomości wodopójek (Hydracarina) wód podziemnych Polski, z opisem czterech nowych gatunków (Contribution à la connaissance des Hydracariens des eaux souterraines de Pologne, avec la description de quatre espèces nouvelles). - Fragm. faun. 20, 7: 77-113.

Chodorowska, W. \& Chodorowski, A. (1958) - Badania fauny wodnej jaskiń tatrzańskich (investigations of water fauna in caves of the Tatra Mts.). - Material y IV Zjazdu Hydrobiologów Polskich w Krakowie.

Chodorowska, W. \& Chodorowski, A. (1960) - Ugrupowania fauny wodnej w jaskiniach tatrzańskich (Groupements de la faune aquatique dans les cavernes des montagnes des Tatras). - Speleologia 2, 1: 57-62.

Chodorowska, W. \& Chodorowski, A. (1963) - Recherches sur la biologie aquatique des grottes des montagnes Tatras. - Actes IIe CIS 2: 94-97.

Chodorowski, A. (1959) - Kilka danych o warunkach środowiskowych zbiorników wodnych w jaskiniach tatrzańskich (Quelques données sur les études du milieu de petits réservoirs d'eau dans les grottes des montagnes Tatras). - Speleologia 1, 1/2: 39-85.

Doroszewski, M. (1960) - Pare uwag o wystepowaniu wymoczków w jaskiniach (Quelques remarques sur l'apparition des Infusoires dans les cavernes). - Speleologia 2, 1: 41-49.

Doroszewski, M. (1963) - L'apparition des Infusoires dans les cavernes des montagnes des Tatras et leur role écologique. - Actes IIe CIS 2: 74-77.

Fischer, E. (1963) - L'eau des réservoirs des grottes des montagnes Tatras au point de vue microbiologique. - Actes IIe CIS 2: 78. 
Gadzińska, E. (1974) - Cernosvitoviella parviseta sp. n. - a new species of Enchytraeidae (Oligochaeta) from the Polish Tatra Mountains. - Bull. Acad. pol. Sci. ser. biol. 22, ó: 403-404.

Gieysztor, M. (1938) - Über eine Turbellarie aus dem Süsswasserpsammon. - Arch. Hydrobiol. Ryb. 11: 364-382.

Golemansky, V. (1969) - Sur une biocénose thécamoebienne peu connue des eaux souterraines littorales des mers. - Abstr. 3rd Int. Congr. Protozool.: 194.

Golemansky, V. (1970) - Contribution à la connaissance des Thécamoebiens (Rhizopoda, Testacea) des eaux souterraines littorales du golf du Gdańsk (Pologne). - Bull. Inst. Zool. Mus. Sofia 32: 77-87.

Golernansky, V. (1973) - Deuxième contribution à la connaissance des Thécamoebiens (Rhizopoda, Testacea) du psammal littoral de la Mer Baltique. - Bull. Inst. Zool. Mus. Sofia 38: 49-60.

Golemansky, V. (1974a) - Lagenidiopsis valkanovi gen. n., sp. n. - un nouveau Thécamoebien (Rhizopoda: Testacea) du psammal supralittoral des mers. - Acta protozool. 13, 1: 1-4.

Golemansky, V. (1974b) - Psammonobiotidae fam. nov. - une nouvelle famille de Thécamoebiens (Rhizopoda, Testacea) du psammal supralittoral des mers. - Acta protozool. 13, 11: 137-14.1.

Grochowski, M. (1904) - O rodzaju studniczka (Niphargus) (On the genus Niphargus). — Kosmos 29: $31-50,81-100,266-301$.

Haeckel, K. (1908) - Niphargus aquilex im Odergebiet. - Zool. Anz. 32: 430-431.

Hrabe, S. (1954) - Rúznonozci - Amphipoda (in:) Klic zvireny CSR, I, Praha.

Jakubisiak, S. (1929) - Sur les Harpacticidae observés en Pologne. - Bull. Soc. Zool. France 54, 3: $191-193$.

Jaworowski, A. (1893a) - Fauna studzienna miast Krakowa i Lwowa (Well fauna of Kraków and Lwów). - Sprawozd. Kom. Fizjogr. PAU 28: 29-48.

Jaworowski, A. (1893b) - Nowe gatunki fauny studziennej miast Krakowa i Lwowa (New species of well fauna of Kraków and Lwów). - Sprawozd. Dyrektora C. K. IV Gimnazjum we Lwowie: 3-44.

Jaworowski, A. (1895) - Neue Arten der Brunnenfauna von Krakau und Lemberg. - Archiv für Naturgeschichte 1, 1: 319-345.

Karaman, G. S. (1974) - 58. Contribution to the knowledge of the Amphipoda. Genus Synurella Wrzes. in Yugoslavia with remarks on its all World known species, their synonymy, bibliography, and distribution (fam. Gammaridae). - Poljoprivreda i sumarstvo 20, 2/3: 83-133.

Kowalski, K. (1951-1954) - Jaskinie Polski (Caves of Poland), I-III, Warszawa.

Kowalski, K. (1955) - Fauna jaskiń Tatr Polskich (Cave fauna of the Polish Tatra Mts.). - Ochr. Przyr. 23: 283-333.

Maschke, K. (1936) - Die Metazoenfauna der Bergwerke bei Mährisch-Altstadt. — Beitr. zur Biol. des Glatzer Schneeberges 2: 175-191.

Micherdziński, W. (1956) - Taksonomia i ekologia Niphargus tatrensis Wrześniowski 1888 (Amphipoda) (Taxonomy and ecology of Niphargus tatrensis). - Ann. zool., 16, 9: 81-134.

Moszyńska, M. (1962) - Skaposzczety Oligochaeta (in:) Katalog fauny Polski, XI, 2, Warszawa.

Moszyński, A. (1936) - Ein neuer Vertreter der Gattung Trichodrilus Clap. (Trichodrilus speleus nov. spec.) aus dem Stollen in Neu-Klessengrund. - Beitr. zur Biol. des Glatzer Schneeberges 2: 214-216.

Pateff, P. (1926) - Süsswasser-Rhizopoden aus der Höhle Salzlöcher (Schlesien). — Mitt. über Höhlen und Karstforschung 2: 46-49.

Pax, F. (1936) - Die Reyersdorfer Tropfsteinhöhle und ihre Tierbevölkerung. - Ibidem 3: 97-122.

Pax, F. \& Maschke, K. (1935) - Die Höhlenfauna des Glatzer Schneeberges. 1. Die rezente Metazoenfauna. - Beitr. zur Biol. des Glatzer Schneeberges 1: 4-72.

Prószyńska, M. (1963) - Les Copepoda Cyclopoida des grottes des montagnes Tatras. - Actes IIe CIS 2: 73 .

Roszczak, R. (1939) - Die Psammitgastrotricha des polnischen Ostseestrandes. - Zool. Pol. 4: 1-23.

Schellenberg, A. (1933) - Weitere deutsche und ausländische Niphargiden. - Zool. Anz. 102, 1/2: 22-33. 
Schellenberg, A. (1935) - Höhlenamphipoden des Glatzer Schneeberges. - Beitr. zur Biol. des Glatzer Schneeberges 1: 72-75.

Schellenberg, A. (1937) - Bemerkungen zu meinem Niphargus-Schlüssel und zur Verbreitung und Variabilität der Arten, nebst Beschreibungen neuer Niphargus-Formen. - Mitt. Zool. Mus. Berlin 22: 1-30.

Skalska, B. \& Skalski, A. W. (1969) - The recent fauna of the Polish caves. - Actes IVe CIS 4/5: 213-223.

Skalski, A. W. (1967) - Charakterystyka wspól czesnej fauny Szczeliny Chochol owskiej w Tatrach (Characteristics of the recent fauna from the Szczelina Chocholowska cave in the Tatra Mts.). - Prace Muzeum Ziemi 11: 281-290.

Skalski, A. W. (1970) - The hypogeous gammarids in Poland. - Acta hydrobiol. 12, 4: 431-437.

Skalski, A. W. (1972) - Distribution des Amphipodes souterrains en Pologne, avec notes sur la variabilité du Niphargus tatrensis Wrześniowski. - Actes I. Coll. Int. Niphargus, Mem. Mus. Civ. St. Nat. Verona 5: 47-53.

Skalski, A. W. (in litt.) - Niphargus casimiriensis sp. n. - a new species of hypogeous gammarid from Poland (Amphipoda, Gammaridae). - Ann. zool.

Stammer, H. J. (1936a) - Die Wasserfauna der Schneeberghöhlen. - Beitr. zur Biol. des Glatzer Schneeberges 2: 199-214.

Stammer, H. J. (1936b) - Die aquatile Fauna der Reyersdorfer Höhle. - Mitt. über Höhlen und Karstforschung 3: 125-129.

Sywula, T. (1974a) - The ostracods (Ostracoda) of the River Raba and of certain aquatic environments connected with it. - Acta hydrobiol. 16, 3/4: 255-271.

Sywula, T. (1974b) - Malzoraczki Ostracoda (in:) Fauna sl odkowodna Polski 24, Warszawa Poznań.

Wisnieuwski, J. (1934a) - Les mâles des Rotifères psammiques. - Mém. Acad. pol Sci. math. nat., 6: 143-165.

Wiszniewski, J. (1934b) - Les Rotifères psammiques. - Ann. Mus. Zool. Pol. 10, 19: 339-399.

Wiszniewski, J. (1935) - Notes sur le psammon II. Rivière Czarna aux environs de Varsovie. Arch. Hydrobiol. Ryb. 9, 3/4: 221-238.

Wiszniewski, J. (1936a) - Notes sur le psammon III. Deux tourbières aux environs de Varsovie. Ibidem 10, 3: 173-187.

Wiszniewski, J. (1936b) - Notes sur le psammon IV-V. - Ibidem 10, 1-3.

Wiszniewski, J. (1937) - Différenciation écologique des Rotifères dans le psammon d'eaux douces. - Ann. Musei Zool. Pol. 12, 1: 1-13.

Wiszniewski, J. (1954) - Fauna wrotków Polski i rejonów przylegy yçh (Rotifera of Poland and adjecent regions). - Pol. Arch. Hydrobiol. 1: 317-490.

Wrześniowski, A. (1888) - O trzech kielzach podziemnych. - Pam. Fizjogr. 8: 1-110.

Wrześniowski, A. (1890) - Über drei unterirdische Gammariden. - Zeit. Wiss. Zool. 50: 600-724.

Vandel, A. (1965) - Biospeleology. The biology of cavernicolous animals, Pergamon Press. 